IRA-International Journal of Management \& Social Sciences

ISSN 2455-2267; Vol.04, Issue 01 (2016)

Institute of Research Advances

http://research-advances.org/index.php/RAJMSS

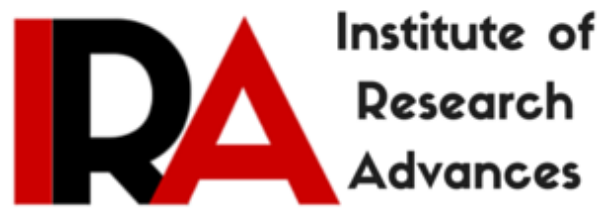

\title{
Urban Dialectics of Caste in Modern India: Reflections from Select Dalit Autobiographical Narratives
}

\section{Bijaya Kumar Sethi}

Research Scholar

Indian Institute of Technology Indore, India.

Amarjeet Nayak

Assistant Professor of English,

Indian Institute of Technology Indore, India.

DOI: http://dx.doi.org/10.21013/jmss.v4.n1.p2

\section{How to cite this paper:}

Sethi, B., \& Nayak, A. (2016). Urban Dialectics of Caste in Modern India: Reflections from Select Dalit Autobiographical Narratives. IRA-International Journal of Management \& Social Sciences (ISSN 2455-2267), 4(1). doi:http://dx.doi.org/10.21013/jmss.v4.n1.p2

(C) Institute of Research Advances

\section{(cc) EY-NC}

This works is licensed under a Creative Commons Attribution-Non Commercial 4.0 International License subject to proper citation to the publication source of the work.

Disclaimer: The scholarly papers as reviewed and published by the Institute of Research Advances (IRA) are the views and opinions of their respective authors and are not the views or opinions of the IRA. The IRA disclaims of any harm or loss caused due to the published content to any party. 


\section{ABSTRACT}

In India, caste is generally seen to be practiced in the villages and the urban spaces are considered to be liberal and casteless under the effect of modern education, industrialization and economic growth. In contrast to the generally perceived notion, the paper, through a systematic analysis of the select instances from the Dalit autobiographical narratives such as Omprakash Valmiki's Joothan, Aravind Malagatti's Government Brahmana and Sharankumar Limbale's Akkarmashi tries to exhibit how the caste structures are very much present in the urban spaces in more sophisticated and complicated forms. It becomes a difficult task for the Dalits who come to the cities to pursue education and livelihood to adjust in such caste ridden spaces. The analysis of the aporia of such conditions and the pain undertaken by the educated Dalits to exist in such caste-ridden urban spaces is the goal of this paper.

"I don’t believe in caste discrimination.

Many harijans come home, have tea and food..." (Malagatti 97)

"Why was I invited here?

To be offered tea? Or to be reminded that I am a harijan?" (98)

The above quotes are from Aravind Malagatti's autobiographical narrative Government Brahmana (1994) wherein the author explains how he felt humiliated by the remarks of an upper-caste friend which indicated the author's low-caste identity, while having a cup of tea in the upper-caste friend's house. The justification provided by the author for feeling humiliated, need not be taken for granted, but it is imperative to analyze whether there was something seriously offensive in the first quoted statement delivered by the educated upper-caste friend, to clarify that he did not believe in caste system. If not, why then did the Dalit friend, who was invited to his upper caste friend's house over a cup of tea, take it otherwise and his inner self started revolting against? Is it justified for the Dalit friend to think that he was invited to be reminded of his harijan identity, rather than being offered a cup of tea? Where did really the problem lie, for which the Dalit friend felt humiliated? Was there a conscious intention of the upper caste friend to humiliate his Dalit friend, or the rhetoric that was used in the conversation itself was humiliating even though it was unintentional? The question raised by the Dalit writer Aravind Malagatti, may not find a straight answer, but it certainly invokes the reader to rethink about the way the urban spaces, such as cities, educational institutions and corporate sectors, are generally portrayed of having caste-less and secular atmosphere. Such caste-less images of the cities have swept the complex practice of caste under the carpet, which is prevalent among the educated mass in the urban areas.

It would not be an exaggeration to say that in the current Indian scenario, caste continues to be a significant force in almost every sector of the society such as politics, employment, formation of colonies and societies in the cities. However, in a few occasions, scholars such as Madhugiri Saroj A. Rao claim that the caste practice in the urban social scenario is weakening. (Rao 1974) Critics like Sonalde Desai and Amaresh Dubey, to some extent subscribe to the same proposition as they contend that, the caste discrimination in metro cities is lessened by education, income and social network. (Desai and Dubey 2011) In contrast to the above mentioned view points, study of Dalit autobiographical narratives such as Omprakash Valmiki's Joothan, Aravind Malagatti's Government Brahmana and Sharankumar Limbale's Akkarmashi leave the impression that caste discrimination is prominent in the urban areas among the educated groups, and economic status in this case matters a little. This contrast in viewpoints between the critics and the Dalit writers holds considerable importance to understand the intricate functions of caste in the urban areas and thus needs to be discussed further. The paper goes through a systematic analysis of the instances from the above mentioned Dalit autobiographical narratives with a primary intention of 
looking into and understanding the kind of emotional trauma the educated Dalits go through to survive in the urban spaces. Secondly, the paper tries to shed light on how the modern assets such as education, urbanization, economic development and seemingly equal distribution of political power fail to wipe away the caste practice.

In modern India, cities are considered to be the hubs of education, employment and trade, as a result of which, a huge chunk of population from the rural area migrates to the cities to pursue higher education and secure jobs. Since the Indian constitution, after independence, has granted Dalits equal rights for education and occupation, a significant number of Dalits, especially educated young Dalits come to the cities seeking higher education and jobs in different fields. Considering the opportunities the cities and towns provide, urban spaces are generally seen as doorways for the socio-economic growth of Dalits. But at the same time, there is always an undercurrent of caste practice in cities, for which the Dalits face different forms of caste discrimination and get alienated in the urban spaces. It is pertinent to note that, there is considerable difference between the forms of caste discrimination Dalits face in the rural areas and the forms of caste discrimination they face in the urban spaces. In villages, there is a clear line of caste boundary which decides the kind of life and relations one should have inside and beyond the line. For instance, Dalits live as untouchables in the outskirts of the villages and are assigned to perform certain menial jobs such as removing the dead animals from the village, cleaning the public latrines, working as bonded laborers in the fields and homes of the landlords, etc. To explain how the Dalits are treated and kept out of the village, Limbale, in his autobiographical narrative, writes, "we are the garbage of the village the village throws out... The umbilical cord between our society and village had snapped, as if the village torn asunder had thrown us out of it." (5) For generations, the relationship between upper castes and Dalits has been that of master- slave. Even after the introduction of the legal provisions in the Indian Constitution for Dalit empowerment, caste discrimination still persists in the rural space with the practice of untouchability, along with the ancestral duty being assigned to the Dalits, which are considered to be inferior and for which Dalits are looked down upon by the upper caste Hindus.

In contrast to the rural space, caste in the urban areas is not always visible in the surface as the practice of untouchability is not directly practiced. Furthermore, the urban educated people project themselves as the refined human beings who completely reject the caste system and consider every human being equal. Perhaps this is what the upper caste friend is trying to do when he tells Malagatti that he does not believe in caste discrimination. But what does he really intend to say, when he says that, many 'harijans' come to his home, have tea and food and he does not mind? It sounds as if the upper caste friend is trying to say, "Malagatti, you are a harijan but I am generous enough in offering a cup of tea to a harijan in my own house". There is no context of caste when the friends are having tea together; it is the friend's statement which reminds Malagatti of his caste identity. Any Dalit in this situation would have thought that he was invited there to be reminded of his harijan identity rather than being offered a cup of tea and so did Malagatti. There could be a possibility that the upper caste friend does not have any ill intention of referring to Malagatti as a harijan, but the deep seated sense of inequality among the Dalits which has been ingrained for ages does not allow them to take such comments easily. On many occasions the upper caste people do not realize that unknowingly they are being offensive toward the Dalits, because of the socio-cultural conditioning they go through since their childhood in a largely upper caste environment. In such critical conditions, life for Dalits in the educated urban society becomes difficult. They hesitate to have relations beyond the caste boundary as there is always a chance of being humiliated at any point of time. Malagatti, in his autobiography, describes another incident which sheds light on how some educated upper caste people talk and write exclusively on caste issues to create their image in the society as intellectual progressive writers, but close encounters with their practical life unmask their real casteist selves. Being trapped in such a situation, Mallagati could not avoid going for a dinner to his upper caste senior's house as his senior caught hold of Malagatti and dragged him to his home. His senior was well known as an "experienced writer and progressive thinker" (101) and whenever he met Malagatti, he used to encourage him saying "you people should walk hand in hand with progressive thinkers... Only then 
can revolution take place. You should mingle with us. Just literature is not enough my boy. Life should be reflected in your writings." (100) Before going for the dinner, to clarify that he is not a casteist, Malagatti's senior conveys that he has an inter-caste marriage. But the aftermath of the dinner was evident enough to shatter the superficial impression his senior was trying to buildup. After having dinner together, as soon as they wash their own utensils, his son comes and takes the utensils inside the house which were used by his father, but the utensils in which Malagatti was having food were left lying there. Malagatti did not mind washing his own plates even though he was a guest, because his senior had kept him informed that his wife had gone to her father's house. But he was shocked when the utensils used by him were not allowed inside the house; it was difficult for him to believe that a person, who talks of proDalit literature, reformation and of being progressive, secretely cultivates caste discrimination in his own house. This hypocritical behavior left him with excruciating mental pain and reminded him of the words of his grandmother:

"If a dalit happened to touch an upper caste person's vessel, it had to be smeared with cow dung and burnt in fire. It would then be immersed in a solution of tamarind and salt. Afterwards, it would be immersed in cow's urine, and only then would it be placed along with the other vessels of house." (102)

Malagatti's is not a unique case; rather thousands of Dalits face the same situation in this so called modern day civilized society. Close reading of many Dalit autobiographical narratives would easily provide the readers similar kind of instances. In his autobiographical narrative, Omprakash Valmiki writes an account of the caste experience in an urban setting, wherein he explicates how the exposition of his Dalit identity brings an end to the relationship between a well educated upper caste family and him. The incident takes place in Bombay when Valmiki was doing his draftsman training in the Ordnance Factory Training Institute. During his training he develops friendship with Vinayak Sadashiv Kulkarni, a Brahmin and a cultural activist, who was staying in a flat near Valmiki's hostel. Kulkarni had mistaken Valmiki as a Brahmin and never asked about his caste identity, neither did Valmiki realize that he had been mistaken as a Brahmin. Kulkarni was nearly of Balmiki's father's age and so developed a fatherly affection towards Valmiki. The intimacy became so strong that Valmiki was frequently invited to Kulkarni's house on different occasions and Mrs. Kulkarni was motherly to him. To express the closeness of the relationship, he was having with the Kulkarnis, Valmiki writes, "the Kulkarni family have given me unstinting affection. They never made me feel like an outsider." (95) But one incident changed the whole scenario. In Kulkarni's house, Prof. Kamble who was a Dalit, was served tea in a different cup whereas the cups in which Mr. Kulkarni, Valmiki and his friend were having tea were similar. When Valmiki asked about this matter to Savita, Mr. Kulkarni's daughter, she replied with disgust, "That Mahar... SC?... The SCs and the Muslims who come to our house, we keep their dishes separate... How can we feed them in the same dishes?" (97). Sabita had started liking Valmiki, but when Valmiki reveals the truth that he is also an SC, she breaks down and starts crying. Thus, Valmiki writes, "she started to cry, as though my being an SC was a crime... Suddenly the distance between us had increased. The hatred of thousands of years had entered our hearts." (98) Even though Kulkarni family was well educated and living in a cosmopolitan city like Bombay, they were not free from caste prejudices. In the cities, caste discrimination is not as transparent as it is in the villages; it is rather veiled. On the other hand, the caste markers in the village are clear which keeps a Dalit always in check in terms of what kind of relation he/she should or should not have with the upper castes; and the upper castes too do not allow the Dalits to cross their boundaries. In the urban spaces, such distinct caste boundaries and restrictions are absent which invites the Dalits to forge social relations beyond their own caste groups. But in the long run, in many cases the Dalits become disillusioned and alienated when they closely experience their relation with the upper castes and find that the hatred towards Dalits is deep rooted in the upper caste culture. Education and modernity do little to get rid of their upper caste consciousness. Life of a Dalit becomes suffocating in such an environment where every relation appears caste-ridden at its root. Therefore, with utter agony Valmiki states, "I find it difficult to survive in such stifling environments, 
where everything seems false." (96) Hence, it would be safe to state that the caste conditions in the urban spaces are complex and the modern machineries like education and urbanization fail to wipe away the discriminatory caste practices.

In the urban spaces, practice of caste is not confined only in the socio-cultural practices; it is much more prominent in employment, education and in spatial segregation also. Trina Vithayathi and Gayatri Singh in their article titled "Spaces of Discrimination: Residential Segregation in Indian Cities" (2012) through the analysis of 2001 Census data, have come with the result that, in the Indian metro cities, "residential segregation by caste is more prominent than the level of segregation by Socio-economic status." (60) The study analyses the data of seven largest metro cities such as Mumbai, Delhi, Kolkata, Chennai, Bangalore, Ahmedabad and Hyderabad. Cities like Ahmedabad and Delhi are found to be on the top of the table in this analysis of spatial segregation by caste. In relation to the result of the study, Sharan Kumar Limbale in his autobiography Akkarmashi describes a similar incident where he finds the whole Latur town divided on caste lines. To explain the spatial segregation in the Latur town he writes, "This city was made of herds of castes. Even localities were identified by castes." (107) In a huge town like Latur, Limbale was unable to get a single room to stay, during his service as a telephone operator and finally he had to stay in the slum. He could get a room in the city when he kept his caste secret but was always petrified by the thought that he could be humiliated and beaten off at the exposition of his caste identity. His experiences were very similar to those of Babasaheb Ambedkar even though they are separated by several decades in time, a further proof to the fact caste discrimination in both rural and urban Indian space continues to be an ugly reality even after Amedkar's staunch socio-political intervention, to strive towards a caste-less society.

In urban India, caste discrimination in the field of education and employment is another important issue. Reservation in the educational institutions and in the government jobs for Scheduled caste candidates has been helpful for the development of the Dalit community. But due to this reservation, on many occasions, many upper caste students and professors in the higher educational institutions become prejudiced against the Dalit students. Thus both their low caste and reservation become the cause of physical and mental torture which they face in different educational institutions. Malagatti reflects on the incidents of his college days when his upper caste classmates used to scold him using his caste and called him 'Government Brahmana' as he was getting benefits from the government's reservation policy. (61) Here, one can see the way the term "Brahmin" is used to signify someone with "high status" and privileges. Whereas Brahmins get both the "high status" in society and privileges just by being born into that caste, the fact that some educated Dalits benefit in terms of education and jobs through the government's reservation policy is seen by the upper caste people to be an act of charity by the government, and hence the disparaging phrase "Government Brahmana". According to the article "Caste and the Metropolitan University" (2002) published by Anveshi Law Committee, in January 2002 ten Dalit students were rusticated from Hyderabad Central University (HCU) and sent to jail for creating violence in the campus. In fact, on January 10, 2002, nearly 100 Dalit students went to the warden's office with complaints against the sudden hike in mess charges and demotion of a Dalit warden to the charge of 'sanitation and gardening'. The discussion went worse and according to the report prepared by the university administration, which came against the group of Dalit students, revealed that the students had beaten up the warden using iron rod and caused major damages in the warden's office. But the fact finding team found no one injured although there was some minor damage to the office. (1100) All the 10 students who were rusticated and sent to jail were academically good students and active members of the Dr Ambedkar Students Association (ASA). Some of the students, who were arrested, were not even present there during the incident. For a minor incident like this, the university administration declared them criminal and handed them over to the police. To describe the rampant practice of caste in such reputed higher educational institutions which are placed in cities, the Anveshi Law Committee reports, "the Dalit students we met were clear that the greatest perpetrator of casteism in their lives was - not their village pump, high school or mofussil college - it was the metropolitan university." (1101) The Anveshi Law 
Committee provides a few instances where the upper caste students in the Hyderabad Central University (HCU) stick notices addressing Dalit students as "pigs", "uncivilized" and "violent brutes". And the professors in the university consider them as "unteachables". (1101) Similar problems are faced in the private job sectors also. A statistical study carried out by The Institute for the Study of Labor (IZA), which is represented in the article "Caste Based Discrimination: Evidence and Policy", based on the responses received by the resumes submitted to different private companies in India, reveals that, the number of the responses the resumes of the Dalit candidates receive is much less than the responses received by the resumes of the upper caste candidates, even though the academic weightage of both the resumes are the same. (31-32) The study was conducted by sending a number of fake resumes to different private companies and the number of calls the resumes received for interview were recorded. Whether a resume belonged to a low caste candidate or a high caste candidate could be easily identified, because the surnames of the candidates given in the resume were clear identity-markers of caste, and hence the castebiased perceptions by the corporate sector, even though the academic weightage of the resumes were kept similar.

According to the Indian laws, caste is not a criterion for recruitment and choosing one's profession, but the scenario is completely different when it comes to practice. In many cities, most of the laborers in the municipal corporation who are employed for cleaning the drains and sweeping the streets belong to the low castes. In the leather industries, there is a high concentration of laborers who belong to Jatav or Chamar castes. No matter whether the people are traditional village dwellers or educated urban dwellers, practices of caste discrimination prevail in a majority of Hindu households. Susan Baily rightly states that "even in the most cosmopolitan professional households, where the values of 'secular' 'anti-casteism' are ardently endorsed, everyday domestic service still commonly draws on caste-defined specialism." (314) In the educated families when they look for a cook and / or housemaid, they try to ensure that the person is from the upper caste. Therefore, it is safe to conclude that that, in $21^{\text {st }}$ century, caste continues to be a difficult problem and it is even more complicated in urban spaces, compared to rural spaces where it is manifested in clear and direct ways. No doubt, the towns and cities function as doorways for Dalits' educational and economic development, as they provide higher education and job opportunities; however, it is imperative not to ignore the numerous ways in which caste discrimination continues to be practiced in the urban space. Modernization, education and urbanization may have changed the traditional forms of caste practice, but the consciousness still operates in the educated minds.

\section{References}

Anveshi Law Committee. "Caste and the Metropolitant University". Economic Political Weekly 37.12 (2002): 23- 29. JSTOR. Web. 5 Dec. 2013.

Baily, Susan, 1999. Caste, Society and Politics in India: From the Eighteenth Century to the Modern age. New York: Cambridge University Press.

Desai, Sonalde and Amaresh Dubey, 2011. "Caste in 21st Century India: Competing Narratives". Economic \& Political Weekly, 46.11. 40-49.

Limbale, Sharankumar, 1984. The Out caste: Akkarmashi. Trans. Santosh Bhoomkar. New Delhi: Oxford University.

Malagatti, Aravinda, 1994. Government Brahmana. Trans. Dharani Devi Malagatti, Janet Vucinich and N. Subramanya. New Delhi: Orient Blackswan.

Rao, M S A., 1974. Urban Sociology in India: Reader and Source Book. New Delhi: Orient Longman. 
Siddique, Zahra, 2008. "Caste Based Discrimination: Evidence and Policy.” Discussion Paper Series: 147. http://ftp.iza.org/dp3737.pdf. Web. 5 Dec. 2013.

Valmiki, Omprakash, 1997. Joothan. Trans. Mukherjee A. P. New Delhi: Radhakrishna prakashan. Vithayathil, Trina and Singh, Gayatri, 2012. "Spaces of Discrimination Residential Segregation in Indian Cities." Economic \& Political Weekly. 37. XLVII: 60-66

http://www.epw.in/system/files/pdf/2012_47/37/Spaces_of_Discrimination.pdf. Web. Jan 22. 2014. 